\title{
To Examine Economic Factors Influencing Citizen Participation in Local Governance in Meru District Council - Tanzania
}

\author{
Imaniel Mosses ${ }^{1}$, Dr. Mike A. Iravo PhD ${ }^{2}$ \\ ${ }^{1,2}$ Jomo Kenyatta University of Agriculture and Technology, P. O. Box 62000-00200, Nairobi, Kenya
}

\begin{abstract}
This study focused on economic factors influencing citizen participation in local governance in Meru district council. The researcher reviewed several literatures and theories, then developed a conceptual framework which helps to identify the knowledge gap from the previous studies. The population size includes $1 \mathrm{DED}, 23 \mathrm{WC}, 3 \mathrm{WEO}, 5 \mathrm{VEOs,} 6$ Village leaders, 15 fifteen cell leaders, as well as 57 ordinary local citizens from different background with gender respectively. Primary data was collected through questionnaires and face to face interviews, while secondary data was collected from document reviews. The qualitative data was descriptively and narratively analyzed by using tables through SPSS. The finding shows the causative agent that weakens participations is the huge income disparities between rich and poor where rich are favorable class and valuable in decision making process than the poor. Therefore MDC is required to come up with strategic ways that can enhance citizens participation in decision making and failure to do so bureaucracy will continue to happens, nepotism, misuse of resources, expansion of marginalization, gender and increase number of uneducated community because those who are stable financially will continue makes decision that will favor a specific group of people and specifically those who are economically good. The researcher recommended that economic empowerment is most important thing in $M D C$. The government has to introduce microfinance, SACCOS, and assures accessible loans to people so that they can be financially stable and reduce burdens of work and unwillingness of citizens when it comes to the issues of participation.
\end{abstract}

Keywords: citizens, participations, governance and local governance

\section{Introduction}

Citizen participation in Tanzania has become popular since 1992 after the introduction of multiparty system. It is considered an essential part in democratic governance since it brings stronger networks between people who live in the same brotherhood. Citizen participation is the social capital because it creates a certain kinds of social networks that enable citizens and communities to access resources and work together to tackle problems for themselves. Citizen participation in the affairs of their community is an important ingredient of democracy and development. According to Richardson (1983) "The opportunity to give the citizen right to take part in the political system is such a fundamental tenet of the democratic system of government that its very existence is rarely questioned. People must be able to have their say to vote, engage in political debate and let those in power know their views on issues which concern them. This is what democracy is all about.

\section{Problem Statement}

Citizen participation means that citizens are part and parcel of what happens in their society or country. The citizens are part of the decision - making process on matters that affect them. Communication is a two-way consultative process. Thus, it is the bottom - up as well as top-bottom before any decision is reached. Villadsen and Lubanga (1996) argued that one of the vital and indispensable pillar /principle or rather tenet of democratic government is citizen participation. In Meru district despite of the World Bank, UNDP, and government of Tanzania takes various initiatives in promoting citizen participation in promoting democratic governance for instance introduction of local government Reform Program, Check and balance system, Ombudsman office, Community based organization, Women empowerment, Provision of loans from WB, Introduction of Public Private Partnership, and establishment of national frame work for Good governance in Tanzania, there is much doubt if the citizens of Meru District are full participate in local government issues, that is why the researcher investigate the economic factors influencing citizen participation in local governance in Meru district council, Tanzania so that they can come up with clear strategies for improving the situation.

\section{Purpose of the Study}

The general objective of the study was to assess the economic factors influence citizens participations in local governance Meru district council, Tanzania. The study sought to identify if is there any relationship between income, means of production and community participations.

\section{Research Methodology}

The study adopted survey design. The design allowed detailed explanation of the problem in the study because is the quick methods of obtaining information about large group of people in a flexible and inexpensive way. The study covered target population of 110 respondents includes 1 DED, 23 WC, 3 WEO, 5 VEOs, 6 Village leaders, 15 fifteen cell leaders, as well as 57 ordinary local citizens from different background with gender respectively. Data was collected directly from the respondent using questionnaires and face to face interviews. Data was descriptive analyzed by using tables through SPSS.

\section{Results and Analysis}

To identify economic factors limiting local citizens to participate in local governance in Meru district council. 


\section{International Journal of Science and Research (IJSR) \\ ISSN (Online): 2319-7064}

Index Copernicus Value (2013): 6.14 | Impact Factor (2015): 6.391

In these objective the researcher evaluate economic variables includes means of production, monthly income and how impact the participation of the members of the community.

\begin{tabular}{|c|c|c|c|c|c|}
\hline \multicolumn{6}{|c|}{ How do you contribute in local government service delivery * What is your monthly average income } \\
\hline Count & & \multicolumn{2}{|c|}{ What is your monthly average income } & Total \\
\hline & Payee & $0<300000$ & $300000<500000$ & $500000<800000$ & \\
\hline \multirow{2}{*}{$\begin{array}{c}\text { How do you contribute in } \\
\text { local government service } \\
\text { delivery }\end{array}$} & developmental contribution & 64 & 6 & 2 & 8 \\
\cline { 2 - 6 } & professional contributions & 0 & 0 & 0 & 88 \\
\hline Total & & 64 & 30 & 1 & 1 \\
\hline
\end{tabular}

Table 1, Respondents contribution in service delivery in relation to their monthly average income

Table 1, Researcher needed to compare the citizens monthly income in relation to what they devote themselves in local government service delivery. From the findings data shows that 64 with average income less than 300,000 provides developmental contribution, 24 with average income between 300,000 and 500,000 also provides developmental contributions, 6 with average income between 300,000 and 500,000 provide tax to contribute to the services delivery and 2 with average income between 500,000 and 800,000 also provide tax and 1 on the same group provide professional contribution. Therefore from the findings, we found that large number of citizens which is 88 from 97 of the sample with diverse income provides developmental contribution such as labor power, cash and information towards service delivery.

From the interview, interviewee responded that their monthly average income range between 500,000 to $1,000,000$ and they said they contribute to the community by paying tax as usual, and provide developmental contribution when they invited in any fundraising programs that targeted to empower the community in all ways of life.

\begin{tabular}{|c|c|c|c|c|c|}
\hline \multicolumn{6}{|c|}{ How do you participate in the local government decision making * What is your means of production } \\
\hline \multirow[t]{2}{*}{ Count } & & \multicolumn{3}{|c|}{ What is your means of production } & \multirow{2}{*}{ Total } \\
\hline & & Employed & Business & 5 & \\
\hline \multirow{4}{*}{$\begin{array}{l}\text { How do you participate in } \\
\text { the local government } \\
\text { decision making }\end{array}$} & I don't participate in any way & 2 & 0 & 64 & 66 \\
\hline & Attending local meetings and committees & 6 & 0 & 0 & 6 \\
\hline & attending some decision making bodies by virtue of my position & 1 & 0 & 0 & 1 \\
\hline & through suggestion box & 0 & 24 & 0 & 24 \\
\hline \multicolumn{2}{|r|}{ Total } & 9 & 24 & 64 & 97 \\
\hline
\end{tabular}

Table 2, ways in which members of community participate in decision making in relation to their means of production

Table 2, the researcher compares the respondent's aggregate source of income and how do they involve in local government decision making. From the findings we found that 64 who work with other informal sectors they don't participate in a anyway, 24 they participate by providing their query, concerns and comment through suggestion box, 6 who are employed attending local meetings and committees, 2 who are employed are not participate in any way and 1 who are employed attending some decision making bodies by virtue of their position. This makes the researcher to understand that 66 of the respondents with diverse means of production are not participate in local government decision making something weakens performance of Meru district council.

From the interview, the interviewee responded that are the public servants and they participate in decision making by actively involved in executive meeting to presents community problems and setting the priorities, arranging the community meeting to discuss with public their concerns, collect citizens complains and actively get involved in any community program for example "weka mazingira safi" are in front line to clean the environment.

\section{Conclusion}

The findings shows that the causative agent that weakens participations is the huge disparities between rich and poor where rich are favorable class and valuable in decision making process than any other group. Therefore MDC has to come up with clear strategies to enhance citizens participation in decision making and failure to do so bureaucracy will continue to happens, nepotism, misuse of resources, expansion of marginalization, gender and increase number of uneducated community because those who are in power will continue makes decision that will favor a specific group of people and specifically those who in rich.

\section{Recommendations}

Economic empowerment, economic empowerment is the process of adding and imparting extra capacity to women and men to participate in and to contribute to any productive sectors so that they can raise their income and benefit from it in ways that recognize the value of their contributions, respect their dignity and make it possible to negotiate a fairer distribution of the benefits of growth. Economic empowerment increases community access to economic resources, giving them confidence to participate in decision making and opportunities including jobs, financial services, property and other productive assets, skills development and market information. Economic empowerment is a prerequisite for sustainable development and is a right of the 


\section{International Journal of Science and Research (IJSR) \\ ISSN (Online): 2319-7064}

Index Copernicus Value (2013): 6.14 | Impact Factor (2015): 6.391

members of the community. Economic empowerment needs sound policies, a holistic approach and long-term commitment from all development actors. MDC can assure his community economic empowerment by providing loans for developmental activities, provides agriculture subsidies and practical training to reduce the number of jobless people in the community and to raise their confidence to participate in decision making processes.

\section{Recommendation for Further Study}

Further investigation for citizens participation in local governance is required to explore the demographic changes in our community and bind them closely to local governance participations, identify which strategies are particularly effective in obtaining bottom up support for strengthen citizen participations in local governance; determine how diversity will promote participations in local governance; and explore the impact of economic empowerment in enhancing participations in local governance

\section{References}

[1] Agrawal A, Gibson CC (1999) Enchantment and Disenchantment: The Role of Community in Natural Resource Conservation. World Development 27, 629649.

[2] Anwar Shah with Sana Shah ( 1989) Public Sector Governance and Accountability series, Local Governance in Developing Countries The World Bank, Washington, D.C.

[3] Bandyopadhyay D (1997), People's Participation in Planning. Economic and Political Weekly, September 27, 1997, pp. 2450-2454.

[4] Barkan J (ed.) (1998), Five Monographs of Decentralization and Democratization in Sub-Saharan Africa, Iowa City, University of Iowa.

[5] Bohme A. (1997), Articulation of Social Actors and Participation: four experiences (mimeo).

[6] Bretas P. (1996), Participative Budgeting in Belo Horizonte: democratization and citizenship. Environment and Urbanization, Vol. 8, No.1.

[7] Buchy M, Ross H, Proctor W (2000) 'Enhancing the information base on participatory approaches in Australian natural resource management: Commissioned research under the Land \& Water Australia's Social and Institutional Research Program.' Land \& Water Australia, Canberra.

[8] Callaway, R. (1979) Teachers' Beliefs Concerning Values and the Functions and Purposes of Schooling, Eric Document Reproduction Service No. ED 177110

[9] Chaligha, A (2008) Local Autonomy and citizen participation in Tanzania; Mkuki na Nyota Publisher; Dar es Salaam.

[10]Crook R. and Manor J. (1998), Democracy and Decentralization in South Asia and West Africa: Participation, Accountability and Performance. Cambridge: Cambridge University Press.

[11]Creswell, H (2005) Planning Education Research Conducting and Evaluating Qualitative and Quantitative. Research Education. INC. New Jersey
[12]Chambers R (1993) 'challenging the Professions: Frontiers for rural development.' (Intermediate Technology Publications: London)

[13] Cox, B (2008), Target population, In pp. lavrakas (Ed.) Encyclopedia of survey research methods. (pp. 876877). Thousand Oaks, CA: SAGE publication, Inc. doi: http://dx:doi.org/10.4135/9781412963947.n571.

[14]Davies, A. (2001). 'What silence knows - planning, public participation and environmental values', Environmental Values, 10: 77-102.

[15]Ddungu, E (1998), Decentralization in Uganda: Process, prospects, and Constraints. Design, in Robinson M. and White G. (Eds.). The democratic Developmental State, Oxford: Oxford University Press.

[16]Edralin J (1997), The new Local Governance and Capacity Building: A Strategic Approach: Examples from Africa, Asia, and Latin America, Regional Development Studies, vol. 3.

[17]Enon J (1998) Education, Research, Statistic and Measurement; Department of Distance Education: Makerere University.

[18]Fischer, F. (2000) Citizens, Experts and the Environment, Durham, NC: Duke University Press,

[19]G. Shabbir Cheema (2005), Building Democratic Institutions: Governance Reform in

[20] Developing Countries, Westport: Kumarian Press,

[21]Goetz, A.M and Jenkins R (1999) Accounts and Accountability: Theoretical Implications of the Right- to ñ Information Movement in India.

[22] Herzer, H and Pirez, P (1991) Municipal Government and Popular Participation. Environment and Urbanization, Vol. 3, No; 1.

[23] Holland J. and Blackburn J. (eds.) (1998), Whose Voice? Participatory research and Policy Change, London: IT Publications.

[24]Holland J. and Blackburn J. (eds.) (1998), Who Changes? Institutionalizing Participation in Development, London: IT Publications.

[25] Hulme D, Turner M (1990) 'Sociology and Development: Theories, policies and practices.' (Harvester Wheatsheaf: New York)

[26] Hussein K (1995) Participatory ideology and practical development: agency control in a fisheries project, Kariba Lake. In 'Power and Participatory Development'. (Ed. S Wright). (Intermediate Technology Publications: London)

[27] IDS, SEARCH, PRIA, Ford Foundation, Kripa, A.P. (1999), Strengthening Participation in Local Governance and the use of participatory methods. Workshop report.

[28] Joanne Moore, John Sanders and Louise Higham (2013), Literature review of research into widening participation to higher education. Report to HEFCE and OFFA by ARC Network.

[29] Jupp, V.(Ed.).(2006),The SAGE Dictionary of Social Research Methods. London, England: SAGE Publication

[30] Kaufmann, D (1999) "Governance Matters" World Bank policy Research department working paper no 2196. Washington DC

[31] Kären M. Hess, Christine Hess Orthmann, Introduction to Law Enforcement and Criminal Justice (2008), p. 1. 


\section{International Journal of Science and Research (IJSR) \\ ISSN (Online): 2319-7064}

Index Copernicus Value (2013): 6.14 | Impact Factor (2015): 6.391

[32] Kolavalli S, Kerr J (2002) Scaling up participatory watershed development in India. Development \& Change 33, 213-235.

[33] Kelly K, Van Vlaenderen H (1995) Evaluating participation processes in community development. Evaluation and Program Planning 18, 371-383

[34] Kyiv, Ukraine (2002), Citizen Participation Handbook, People's Voice Project International Centre for Policy Studies, iMedia Ltd.

[35]Lister R. (1998), Citizen in Action: citizenship and Community Development in a Northern Ireland context, Community Development Journal, Vol. 33 No. 3, July.

[36]Lane J (1995) Non-governmental organizations and participatory development: the concept in theory versus the concept in practice. In 'Power and Participatory Development'. (Ed. S Wright). (Intermediate Technology Publications: London)

[37]Manor J. (1998) The Political Economy of Decentralization. New York Press. US

[38] Makumbe M (1998), Decentralization, Democracy, and Development in Zimbabwe, in: Nickson A. (1998), where is Local Government Going in Latin America? A comparative perspective, [online] Available: URL: http://bham.ac.uk/IDD/ranslas.htm

[39] Matsumoto D (1996) Culture and Psychology. Pacific Grove, CA: Brooks/Cole. New Law Journal - Volume 123, Part 1

[40] Mc Guigan J.R, Moyer, R.C, Harris F. H (2005) Managerial economics; application, strategy and tactics, Thompson Corporation, Ohio

[41] Michels, A (2011)'Innovations in Democratic Governance: How Does Citizen Participation Contribute to a Better Democracy?' International Review of Administrative Sciences.

[42] Midgley J, Hall A, Hardiman M, Narine D (Eds) (1986) 'Community participation, social development and the state.' (Methuen: London ; New York)

[43] Minogue M. (1997) The Principles and Practice of Good Governance. British Council Briefing, Law and Governance.

[44]Mukandara R. (1998), Decentralization and Democratization in Tanzania, in: Barkan J (ed.), Five Monographs on Decentralization and Democratization in Sub-Saharan Africa, Iowa City, Universisty of Iowa.

[45] Mutizwa-Mangiza and Conyers (1996), Decentralization in Practice, with Special Reference to Tanzania, Zimbabwe, and Nigeria. Regional Development Dialogue, Vol17.

[46] Mompati T, Prinsen G (2000) Ethnicity and participatory development methods in Botswana: some participants are to be seen and not heard. Development in Practice 10, 625-638.

[47] Ndekha A, Hansen EH, Molgaard P, Woelk G, Furu P (2003) Community participation as an interactive learning process: experiences from a schistosomiasis control project in Zimbabwe. Acta Tropica.

[48] Nelson N, Wright S (1995) Participation and power. In 'Power and participatory development'. (Ed. S Wright). (Intermediate Technology Publications: London)

[49] Owens, S. (2000). 'Engaging the public: information and deliberation in environmental policy', Environment and Planning A, 32: 1141-8.
[50] Oldenburg, P. (1999), Non-Governmental Organizations and Panchayati Raj. Occasional Paper No. 5, New Delhi: PRIA.

[51]Parry, G., Moyser, G. and Day N. (1992), Political Participation and Democracy in Britain. Cambridge: Cambridge University Press.

[52] Pellizzoni, L. (2003): 'Uncertainty and Participatory Democracy', Environmental Values 12.

[53] Peet R, Hartwick E (1999) 'Theories of Development.' (The Guildford Press: London)

[54] Porio E. (1996), Urban Governance in Southeast Asia: implications for Sustainable Human Settlements, in P. McCarney (Ed.). Cities and Governance: new directions in Latin America, Asia and Africa. Toronto, University of Toronto Press.

[55] Robert A.D (1998) On Democracy, London: Yale University Press.

[56] Robinson, M. (1998.), Democracy, Participation, and Public Policy: The Politics of Institutional

[57]Rhodes, R. (1996), The new Governance: Governing without Government. Political Studies.

[58] Rowe, G. and Frewer, L.J. (2000) Public participation methods: A framework for evaluation, Science, Technology, \& Human Values.

[59] Rowe, G and Gammack, J (2004) Promise and perils of electronic public engagement, Science and Public Policy. UK

[60] Rowe, G. and Frewer, L (2005)A typology of public engagement mechanisms, Science, Technology, \& Human Values.

[61] Schneider H. (1999). Participatory Governance: The Missing link for poverty Reduction. OECD Policy Brief.

[62] Sch nwwalder, G. (1997), New Democratic spaces at the Grassroots? Popular Participation in Latin America local Governments, Development and Change, 28/4:753-70.

[63] Spencer-Oatey, H. (2008) Culturally Speaking. Culture, Communication and Politeness Theory. $2^{\text {nd }}$ edition. London: Continuum.

[64] Stiefel M. and Wolfe M. (1994), A Voice for the Excluded: Popular participation in Development: Utopia or Necessity? London: Zed Books.

[65] Storey D (1999) Issues of Integration, Participation and Empowerment in Rural Development: The Case of LEADER in the Republic of Ireland. Journal of Rural Studies.

[66] Tikare S, Youssef D, Donnelly-Roark P, Shah P (2001) 'Organising participatory processes in the PRSP.'

[67]Tristan Claridge(2004), Designing Social Capital SensitiveParticipation Methodologies

[68] Verba S. and Nie, N. (1972), Participation in America: Political Democracy and Social Equality. New York: Harper and Row Publishers.

[69] Velaquez, F (1991). Local Governments in Intermediate Cities in Colombia; Municipal Administration: for whom? Environment and Urbanization, Vol. 3, No.1.

[70] Walker J (2004) What does it mean to be a citizen, http://www.responsiblecitizen.co.uk/what-it-means-tobe-a-citizen.html

[71] Walker G, Kogut B (1997) Social Capital, Structural Holes and the Formation of an Industry Network. 


\section{International Journal of Science and Research (IJSR) \\ ISSN (Online): 2319-7064}

Index Copernicus Value (2013): 6.14 | Impact Factor (2015): 6.391

Organization Science: A Journal of the Institute of Management Sciences.

[72] Welsch, G. A, Hilton R.W, Gordon P.N. (2004) (5th edition) Budgeting: Profit and Control, Prentice Hall of India, New Delhi.

[73] World Bank, (1995), Better Urban Services: finding the Right Incentives. Washington, DC: The Bank.

Volume 5 Issue 6, June 2016 www.ijsr.net

Licensed Under Creative Commons Attribution CC BY 